\title{
WOOD DECAY IN SILICIFIED GYMNOSPERMS FROM ANTARCTICA
}

\author{
SARA P. STUBBLEFIELD AND THOMAS N. TAYLOR
}

Department of Botany, Ohio State University, Columbus, Ohio 43210

\begin{abstract}
Gymnospermous secondary xylem degraded by wood-decaying fungi was examined in silicified fossils from Antarctica. Araucarioxylon-type wood from the Triassic and specimens of Vertebraria from the Permian demonstrate similar patterns of decay. Specimens are characterized by irregularly shaped areas lacking cells and are infected with branched, septate hyphae with clamp connections. The decay in these fossils is comparable in appearance to present-day rots caused by basidiomycetes. Two patterns of decay are evident: (1) A wall component, presumably lignin, is removed from the wall and middle lamella of infected tracheids. leaving a considerably thinner cellulose framework; and (2) the primary and secondary walls typically separate, and all wall layers are progressively reduced in thickness and eventually removed. The middle lamella, particularly where it is thickest in the corners between cells, persists longer than other layers. Indications of host response to fungal attack include the production of possible wall appositions. Evidence of wood decay occurs as early as the Upper Devonian, and all reported cases from the fossil record are similar to those found today.
\end{abstract}

\section{Introduction}

Fungi are the major decomposers of higher plants in modern-day ecosystems (OTJEN and BLANCHETTE 1984) and were undoubtedly important in the geologic past. However, the first appearance of fungi with the ability to degrade lignified plant tissues is not clearly marked in the fossil record, and wood decay caused by fungi has not been documented prior to the Upper Devonian (STUBbLEFIELD et al. 1985). Because paleobotanical interest has usually centered on well-preserved material rather than on decayed or degraded specimens, instances of fossil wood rot have not been examined in detail. Here we expand the fossil record of wood decay by documenting two examples of wood rot caused by fungal activity in gymnospermous wood from the Permian and Triassic of Antarctica. Similar patterns of decay occur in both instances and show features characteristic of both white rot and white-pocket rot in extant woods.

\section{Material and methods}

The specimens in this study were collected by JAMES M. SCHOPF and other members of the Institute for Polar Studies, Ohio State University, during the late 1960s and early 1970s in the Transantarctic Mountains of Antarctica. Secondary xylem of the Araucarioxylon type comes from the Fremouw Peak locality in the Beardmore Glacier area where wood specimens occur in the Fremouw Formation of the Victoria Group, Upper Beacon Supergroup, and are Triassic in age (BARRETT 1970). Material includes stems with a primary plant body as well as fragments of wood. Specimens of Ver-

Manuscript received May 1985; revised manuscript received September 1985

Address for correspondence and reprints: SARA P. STUBbLE FIELD, Department of Botany, Ohio State University, 1735 Neil Avenue, Columbus, Ohio 43210. tebraria were collected at Mount Augusta, also in the Beardmore Glacier area, from the Buckley Formation and are middle or late Permian in age (SCHOPF 1970). Vertebraria is regarded as the aerenchymatous root of certain glossopterids with Araucarioxylon type wood (GOULD and DELEVORYAS 1977).

Both Araucarioxylon and Vertebraria were examined by light (LM) and scanning electron microscopy (SEM). Cellulose acetate peels were prepared after the surface of the specimen was etched ca. $2 \mathrm{~min}$ in $48 \%$ hydrofluoric acid. Peels were mounted in Coverbond for LM. Small areas were cut from the specimens and etched more deeply for SEM; they were then rinsed, critical-point dried, and mounted on standard SEM stubs for study. SEM was not useful in examining hyphae from either locality because the silicate infilling of each tracheid and the encased fungi were lost from the cell before the hyphae were freed. However, tracheid walls of Araucarioxylon were suitable for SEM and were examined for indication of fungal damage. In contrast, both the secondary xylem and fungal hyphae in specimens of Vertebraria were poorly preserved and did not withstand the etching necessary for SEM. Fine details of fungal structure and tracheid damage were not available in these specimens.

\section{Observations}

Both Araucarioxylon (PRASAD 1982) and Vertebraria (SCHOPF 1965) are characterized by pycnoxylic wood. Fungi are often present in both the tracheids and rays of the secondary xylem of infected specimens as well as in the periderm. The macroscopic appearance of the decayed woods is similar in both genera.

\section{ARAUCARIOXYLON}

Both infected and uninfected specimens of $A r$ aucarioxylon were available for study, and nearly 
80 specimens exhibited some degree of decay. The distribution of decayed areas varies. In some specimens they are distributed throughout the stem (fig. $1)$, while in others the pockets of decay are restricted to a segment of the specimen. Individual pockets may fall entirely within a growth ring (fig. 1 , arrow) or may cut across the boundary between rings (fig. 1). In the center of some stems, the decayed regions sometimes appear to be arranged in more or less regular concentric rings lying along the boundary between adjacent growth layers (fig. 1). However, this pattern does not occur in all specimens, and areas of decay are not preferentially located across growth rings. In a survey of 300 pockets, ca. $45 \%$ of the pockets that were narrower than adjacent growth rings were contained completely within a single growth ring.

Individual pockets are circular to irregular in cross section and range up to $3.5 \mathrm{~mm}$ in diameter (fig. 1). In longitudinal section, pockets are usually somewhat spindle-shaped (fig. 2). The longest pockets are ca. $3 \mathrm{~cm}$ but were observed only in incomplete specimens. Pockets of decay are often entirely free of cellular debris. However, portions of partially decayed cells along the margins of pockets may persist (figs. 9, 19). Concentric patterns within the cavities (SCHOPF 1971) reflect mineralization.

Hyphae up to $6.5 \mu \mathrm{m}$ in diameter are found in pockets as well as in tracheids and ray parenchyma (figs. 3, 5, 7). They are branched and septate and exhibit both simple (fig. 4) and medallion clamp connections (fig. 5). Hyphae extend through radial (fig. 5) and tangential walls and in some instances apparently pass from cell to cell through pits (fig. $6)$. The presence of bore holes was sometimes suggested in LM observations but could not be verified. Although various other features characteristic of fungal attack, such as erosion troughs or microscopic pockets in the secondary walls, are not observed, degraded pits are common (fig. 20).

Partially degraded cells in intermediate stages of decay sometimes occur adjacent to pockets. The radial and tangential walls of these tracheids are thin, although tangential walls may persist longer than radial walls (fig. 8). The most striking feature of these cells is the persistence of the corner areas between four adjacent cells where the middle lamella is thickest (fig. 8).

Up to four different wall layers are observed in secondary tracheids. The most prominent is often evenly swollen and separated from the other layers of the wall (figs. 11-13). In other cells this wall layer is markedly and unevenly enlarged (figs. 17, $18)$, nearly occluding the tracheid lumen. The' wall in these tracheids intergrades in appearance with the evenly swollen walls of other cells (fig. 12). The distribution of cells with pronounced uneven thickenings is not consistent. While they some- times occur in a several-layered band among the smaller cells of the latewood, they may also be distributed throughout the growth ring. Although they are not restricted to one area of an axis, neither do they form a continuous ring around a stem.

Adjacent to the thickened layer in the direction of the cell lumen is a much thinner, dark layer (figs. $10,17)$ that is sometimes separated from the thickened layer and often persists when it is no longer present (fig. 10, bottom arrow). Although this is apparently the innermost layer of the cell wall, it is not visible in all cells (figs. 9, 14). An additional wall layer may also be visible toward the outside of the cell (figs. 12, 13, arrows). This layer is also most easily seen when it is separated from adjacent layers. Apart from transmission electron microscopy, it is difficult to interpret these wall layers. However, the thickest secondary wall layer occupies the position of the $S_{2}$ layer. Bounding it are layers corresponding in position to the $S_{1}$ and $S_{3}$ layers. The compound middle lamella (i.e., middle lamella and primary wall) is evident in the corners between cells but is difficult to distinguish from the supposed $S_{1}$ layer along the radial and tangential walls.

An additional variation in wood structure involves differences in the densities of cell walls. This is most obvious in peel preparations in which dark wood is adjacent to very light wood and indicates differences in the amount or type of organic material present (figs. 15, 16). These areas persist through a number of peels, suggesting that they are not the result of random unevenness in etching. While they sometimes occur along cracks, they are also present as discrete regions apart from cracks and are similar in size and shape to empty pockets. They are found deep within a stem as well as near its periphery and may be deep within the fossil as well. Cellular outlines are clear in this region, but the thickness of the walls and the amount of the remaining organic matter are markedly reduced (figs. 17, 18). The middle lamella is typically absent (fig. 15), and adjacent cells are generally separated. In most cases a single layer of the cell wall persists (fig. 15). Sometimes an additional layer, apparently corresponding to the $\mathrm{S}_{3}$ layer in other cells, is also present (fig. 16, arrow).

\section{VERTEBRARIA}

Decayed axes of Vertebraria differ from those of Araucarioxylon only in minor respects. Pockets are more irregularly shaped in cross section, often tangentially elongated (fig. 21), and reach $13 \mathrm{~mm}$ in maximum diameter. In longitudinal view they are tapered (fig. 22). Decayed regions are scattered, and the impression of concentric rings of decay is less pronounced (fig. 21) than in some specimens of Araucarioxylon.

Branching hyphae are observed in both tracheids 


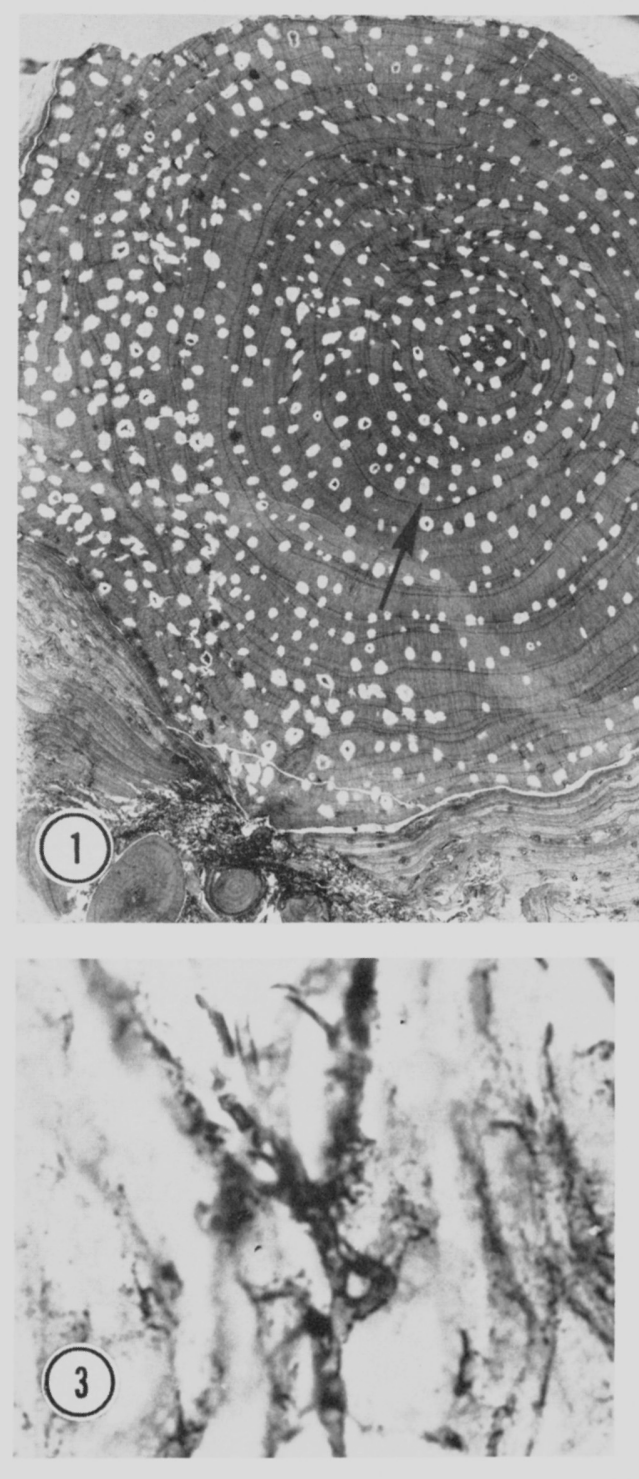

कa
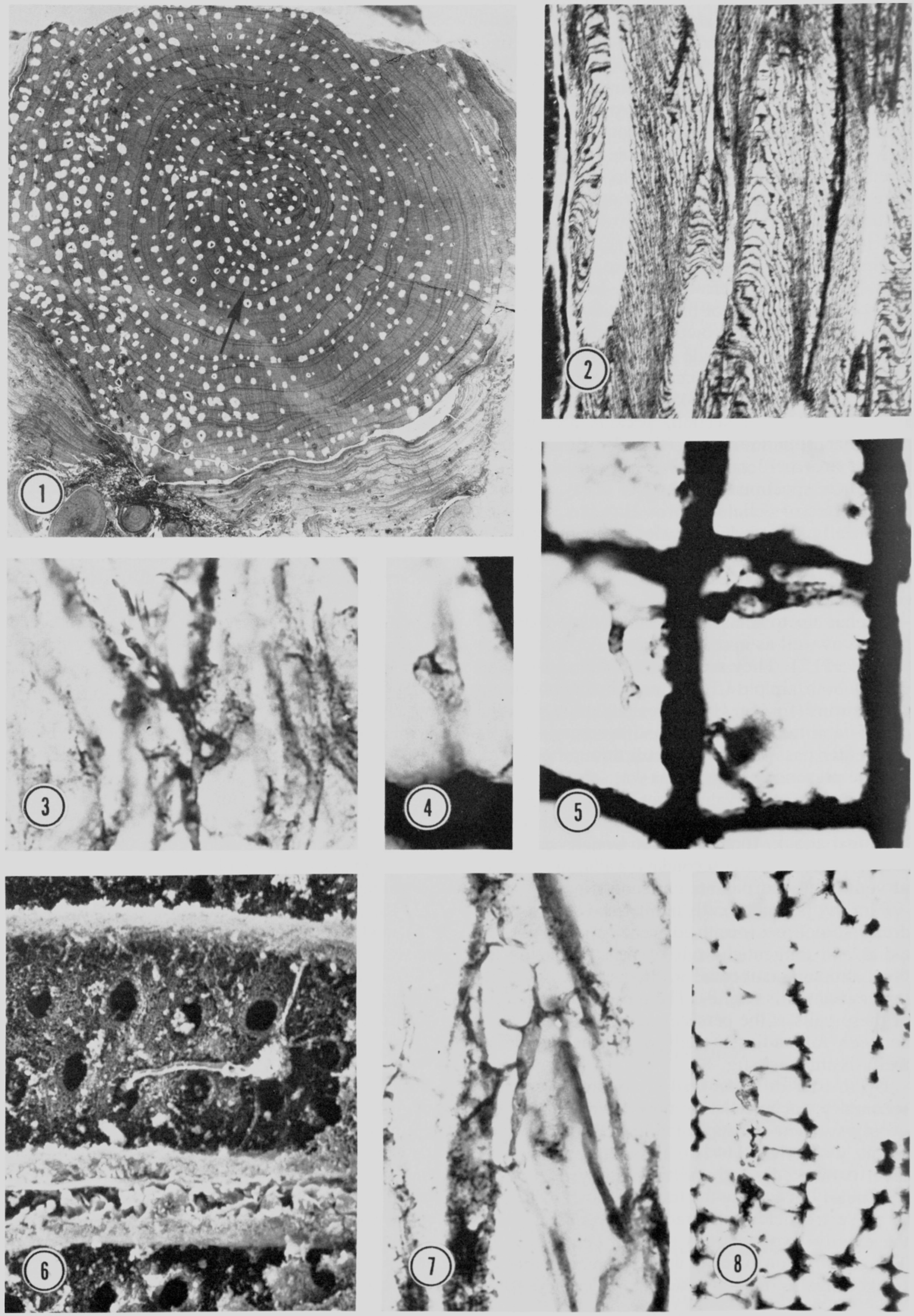

b-

int

(8) 15 
and rays (fig. 25) as well as in the periderm of decayed axes (fig. 23). They are very poorly preserved and show little detail. Hyphae pass through both tangential (fig. 26) and radial walls. Partially degraded cells near cavities of decay show changes comparable to those in Araucarioxylon. However, unevenly thickened walls have not been observed. Collapsed tracheids are not common, although wood is often characterized by irregular, disrupted growth rings (fig. 24).

\section{Discussion}

\section{CAuses of PERForated WOOD}

INSECTS. - Among the most common causes of perforated fossil wood are boring insects, particularly beetles. Examples of beetle attack that may be compared with our material have been described (BRUES 1936; WALKER 1938; LiNCK 1949; CiCHAN and TAYLOR 1982), but despite superficial similarity in the pattern of damage, we reject insect activity as a cause of the perforations in our wood for several reasons: (1) The perforations vary greatly in size. (2) They are remarkably clean and free of any indication of animal activity, including frass. (3) They are discrete and do not form the anastomosing network of burrows that sometimes characterizes beetle borings (CICHAN and TAYLOR 1982).

(4) There are well-marked areas of incipient perforation that are inconsistent with insect activity.

DiFFERENTIAL MINERALIZATION.-Eocene wood, similar in appearance to our wood, was described from the Yellowstone fossil forests, but the "borings" in this wood were actually isolated groups of calcified cells in a generally silicified wood (FISK and FrITZ 1984). Although this wood resembled secondary xylem attacked by insects, cellular structure was preserved within the calcified areas. Our specimens of Araucarioxylon and Vertebraria contrast markedly with the Eocene wood. In most places in our specimens, perforated areas are free of any cellular outlines and are clearly holes. In those areas in which cell outlines were visible and some organic matter was retained, cell walls, particularly the middle lamella, have been selectively modified. This is not characteristic of pseudoborings caused by differential mineralization.

FUNGAL ACTIVITY.- - Fungal activity is indicated in our material both by hyphae with clamp connections within the wood and by a macroscopic and microscopic decay pattern similar to that in modern plants attacked by fungi. Acellular pockets, ap- parently delignified regions, and modifications in the walls of some tracheids are consistent with fungal rot.

\section{PATTERNS OF DECAY}

Two patterns of decay occur in the secondary xylem of Araucarioxylon. The first appears in those regions of wood that are light in color and reflects a reduction in the amount of organic content in the cell walls in comparison with adjacent cells. Tissue with this distinctive appearance was also noted in specimens of Vertebraria by SCHOPF (fig. 16 in SCHOPF 1971), who attributed the modification to weathering. In our opinion, weathering does not satisfactorily explain all of the light areas in our material. Although weathering subsequent to permineralization occurs and is sometimes responsible for the removal of organic material (SIGLEO 1978), it is unlikely that it would affect scattered, discrete areas deep within an axis when surrounding cells are unmodified. Such areas resemble empty decay pockets in size, shape, and distribution. We suggest that the reduction of organic material in many of these areas may reflect the modification of wood by fungal decay.

SCURFIELD (1979) suggested that permineralization involves the dissolution of cell wall components beginning with lignin. In illustrating stages in silicification, he figured wood with swollen cell walls; enlarged, empty, or filled intercellular regions; and modified cell lumina (figs. 1-5 in SCURFIELD 1979). He also demonstrated the presence of fungi and bacteria in these woods but did not evaluate fungal damage or differentiate changes in wall structure caused by silicification from those that may have been caused by wood-decaying fungi. Because wood decay in extant plants causes many of the same changes in the walls of secondary $x y-$ lem, some of the changes in wood structure observed by SCURFIELD (1979) and seen in our material, particularly the removal of lignin, may have been instead a result of fungal activity.

A second pattern of decay is indicated by partially degraded cells at the margins of pockets and by modifications of the cell walls in nearby tissue In contrast to the first pattern of decay, the middle lamella is not selectively removed, but partially decayed cells immediately adjacent to cavities are often held together at the corners in the area of the thickest and most heavily lignified middle lamella even after the tangential and/or radial walls have been completely removed. In addition, the secondary wall

Figs. 1-8.-Araucarioxylon. Fig. 1, Cross section of axis with numerous pockets of decay. Arrow indicates decay pocket within a single growth ring. Ant 70-9-104a; $\times 1$ 1.1. Fig. 2, Longitudinal section with spindle-shaped pockets. CB 358: $\times 7$. Fig. 3. Hypha with medallion clamp connection. CB 357A-1(s-1): $\times$ 780. Fig. 4, Hypha and clamp connection. CB 357-B-3B: 1.040. Fig. 5. Branched hypha penetrating tracheid walls. CB 357-B-3B: $\times 1,040$. Fig. 6, Hypha penetrating pit in tracheid wall. $\times 1,000$. Fig. 7, Branching hyphal tip. CB 357A-1(S-1); $\times 840$. Fig. 8. Degraded cells adjacent to decay pocket. Note persistence of middle lamella at thickened cell corners. CB $357 \mathrm{~B}-3 \mathrm{~B} ; \times 400$ 
$5+3$
+110 *14. nt? + at $x+x$ $-7+2$ (3) (p)
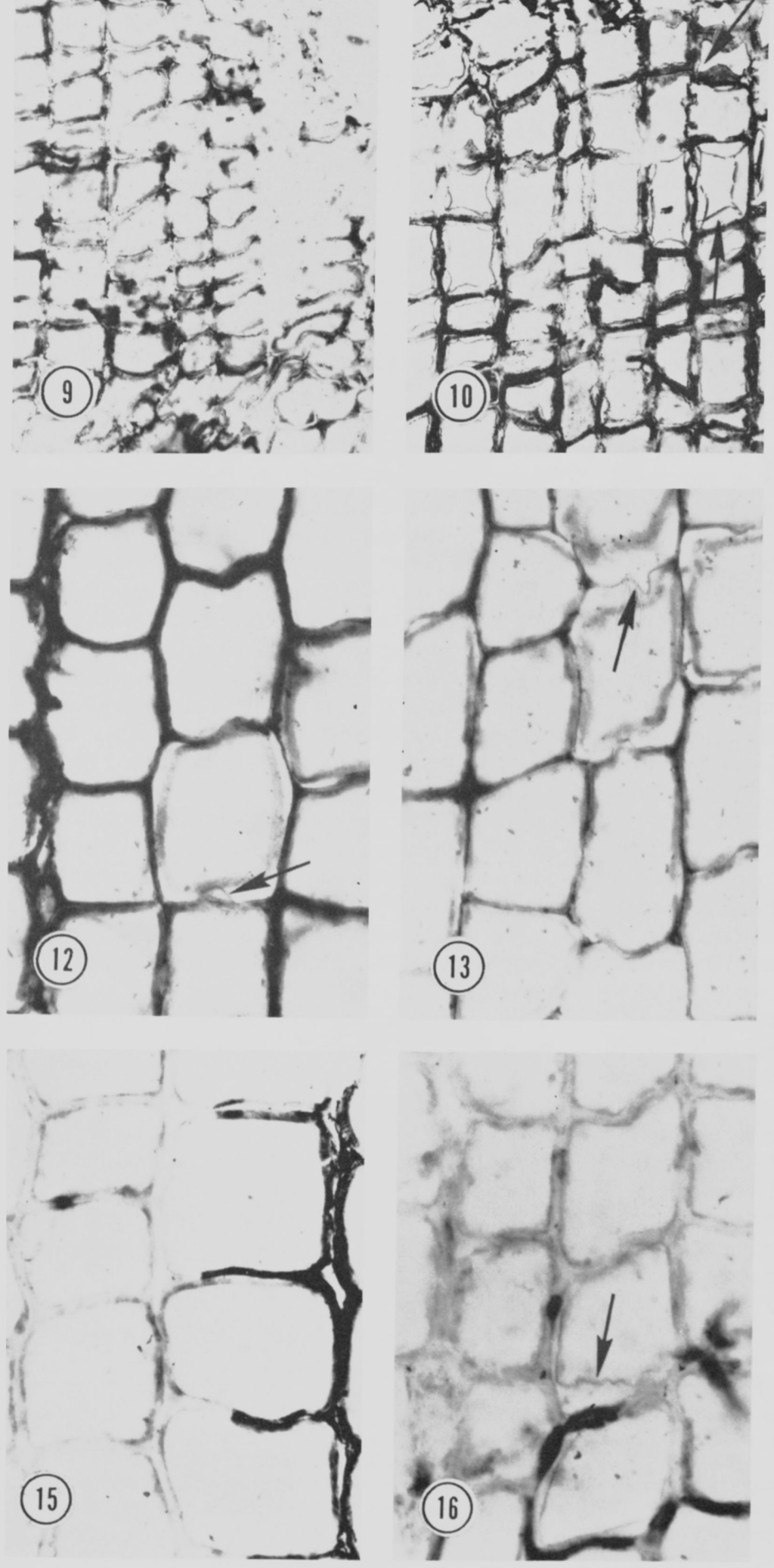
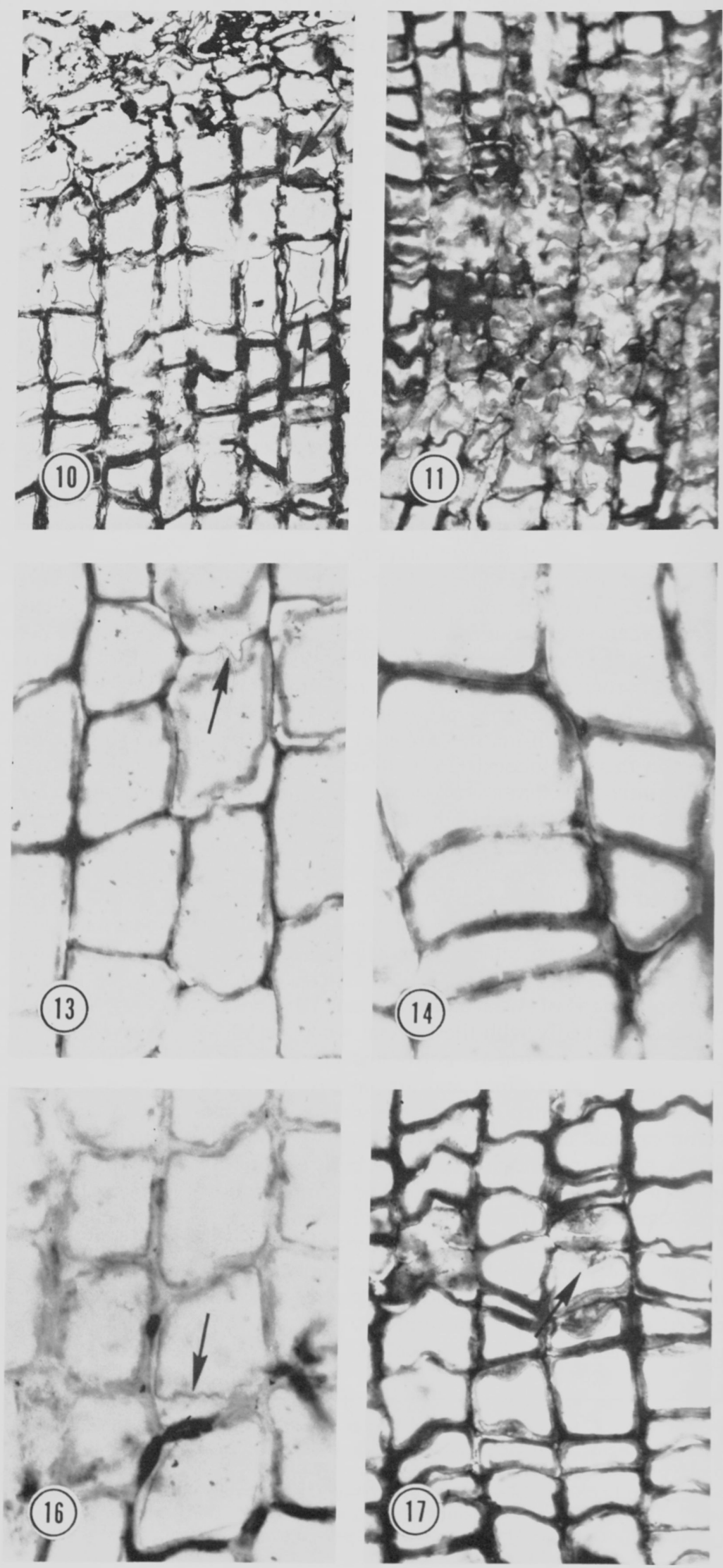

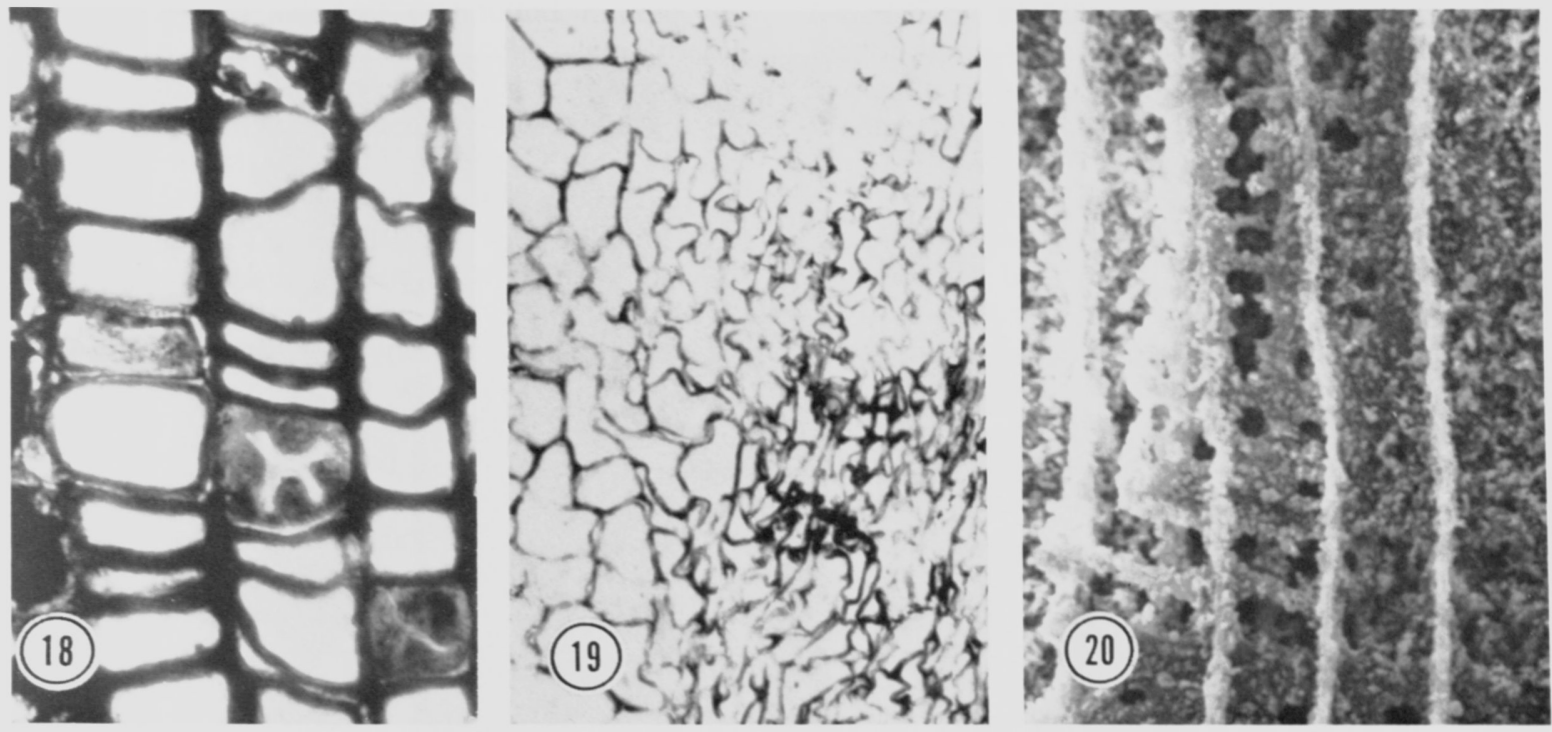

Figs. 18-20.-Araucarioxylon. Fig. 18, Wall appositions and expanded secondary wall. 357B B-4b; × 415. Fig. 19, Collapsed tissue adjacent to decay pocket. CB 357D T-5a: $\times 175$. Fig. 20. Tracheids with damaged pits. $\times 300$

customarily separates from the compound middle lamella and is lighter in color than unseparated walls. There is also some indication of swelling in the secondary wall that, in its most extreme form, intergrades with the elaborated thickenings. This pattern of decay is characterized by the progressive thinning and ultimate destruction of the primary and secondary wall and, finally, the middle lamella.

COMPARISON WITH DECAY IN EXTANT PLANTS.Three primary types of decay caused by fungi are customarily recognized in extant plants: white rot, brown rot, and soft rot (MONTGOMARY 1982). Decay caused by white rot fungi varies and includes white-pocket rot, white-mottled rot, and simultaneous white rot (BLANCHETTE 1984). Each type of decay can be related to particular groups of organisms with characteristic enzymatic activities that, in turn, are reflected in different patterns of decay and in distinctive macroscopic and microscopic modifications of wood structure. The decay seen in Araucarioxylon and Vertebraria shows features of both white rot and white-pocket rot.

Today, both white and white-pocket rot are caused by members of the Basidiomycotina (BOYCE 1961). Some of these, such as the widely distributed Phel- linus (Fomes) pini (Thore ex Fr.) A. Ames, cause decay in softwoods, while others, including Fomes nigrolimitatus (Rom.) Bourd. and Galz., Inonotus (Polyporus) tomentosus (Fr.) S. C. Teng, and $X y$ lobolus (Stereum) frustulatus, infect hardwoods. Despite substantial anatomical differences in hardwoods and softwoods, the general pattern of decay is similar for a given type of rot (BLANCHETTE 1984).

White rot has been well characterized with SEM (e.g., Bravery 1971; Jutte and Zabel 1974; LeVy 1974; BlanChETte 1980a; ERIKSSON et al. 1980) Typically, white-rot proceeds from the $\mathrm{S}_{3}$ layer outward as hyphae erode the cell wall, forming erosion troughs that eventually coalesce to degrade the cell. In this type of decay, cellulose and lignin are usually degraded in a 1:1 ratio (CowLING 1961). Unfortunately, submicroscopic features of decay in our material were not readily visible because the fossils were unsuitable for SEM. However, the similarity between partially degraded fossil cells and present-day white rot, as seen in LM, is striking. WILCOX (1968) illustrated progressive stages of decay in sweetgum (Liquidambar styraciflua) that involved the thinning of the secondary wall, resulting in its removal, and the persistence of re-

Figs. 9-17.-Araucarioxylon. Fig. 9, Degraded tracheids adjacent to decay pocket. Note absence of radial walls in many cells and modification of secondary walls. CB 357D T-5a: $\times 230$. Fig. 10, Cellular degradation with separation of innermost layer of secondary wall (arrows). CB 357D T-5a: $\times 275$. Fig. 11, Early stage in formation of decay pocket. CB 357B-4b: $\times 235$. Fig 12. Degraded cell illustrating enlargement and separation of secondary wall. Arrow points to thin wall layer in region of $\mathrm{S}_{1}$ layer or primary wall. CB 357B-B-3B; $\times 390$. Fig. 13, Degraded tracheids. Note thinning of all wall layers in some cells and swelling of secondary wall in others. Arrow points to thin wall layer in region of $\mathrm{S}_{1}$ layer or primary wall. CB 357D T-5a; $\times 325$. Fig. 14. Degraded cells with thin areas, possibly bore holes in primary and secondary wall. CB 357D T-5a: $\times 400$. Fig. 15, Degraded tracheids showing absence of compound middle lamella, thinning of walls, and differential removal of organic material. CB 357D T-5a: $\times 410$. Fig. 16. Tracheids in region of decay. Note separated inner wall layer (arrow) and absence of middle lamella. CB 357B-3b: $\times$ 400. Fig. 17, Possible wall appositions and $\mathrm{S}_{3}$ layer (arrow). CB 357B B-4B; $\times 400$. 

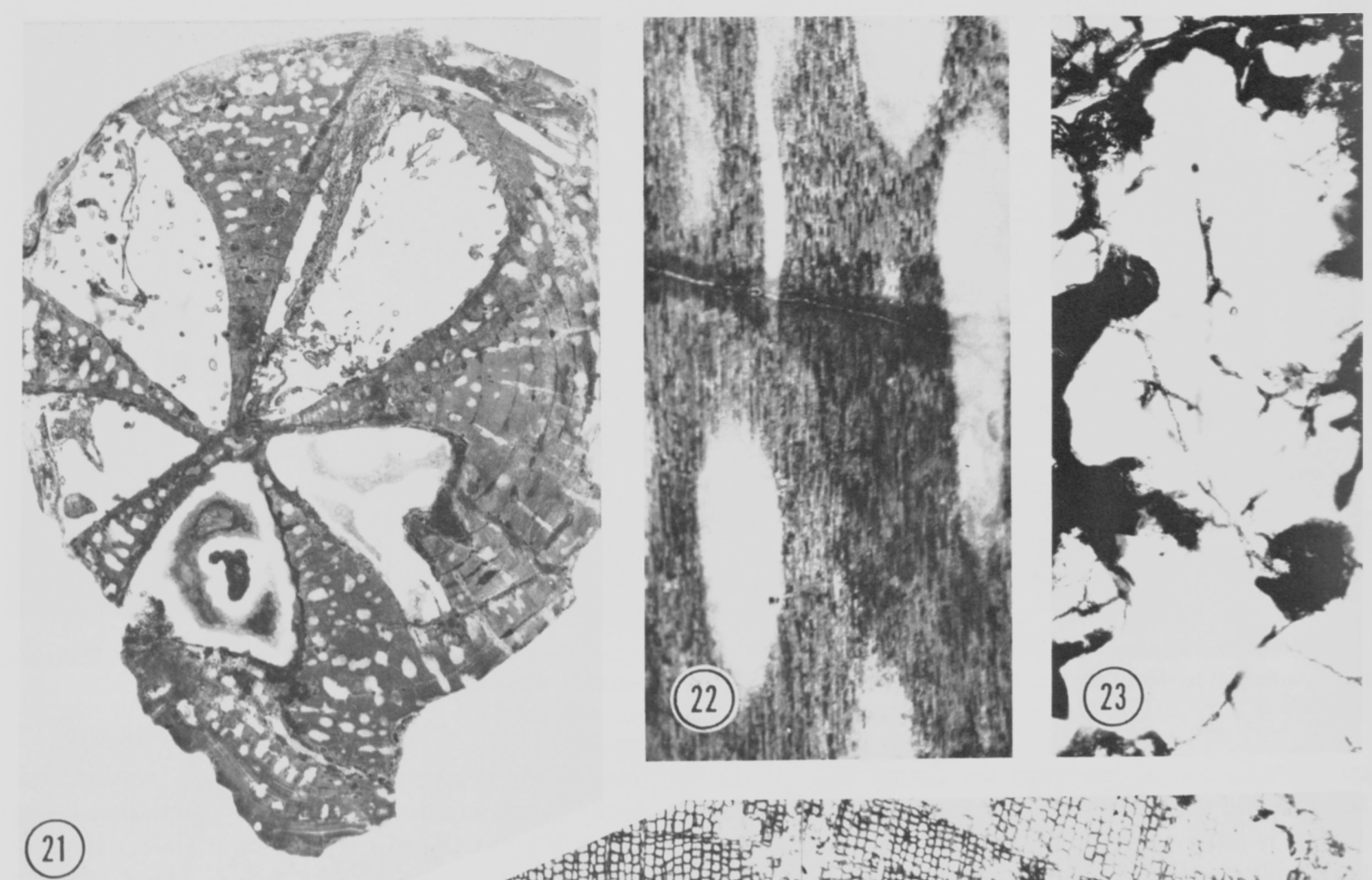

(21)

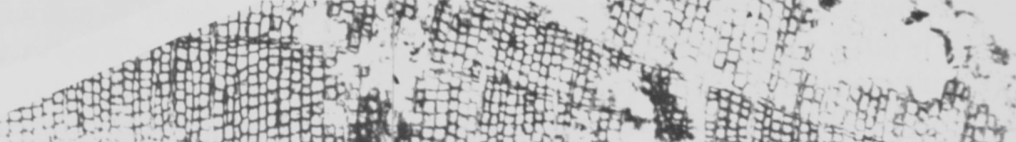
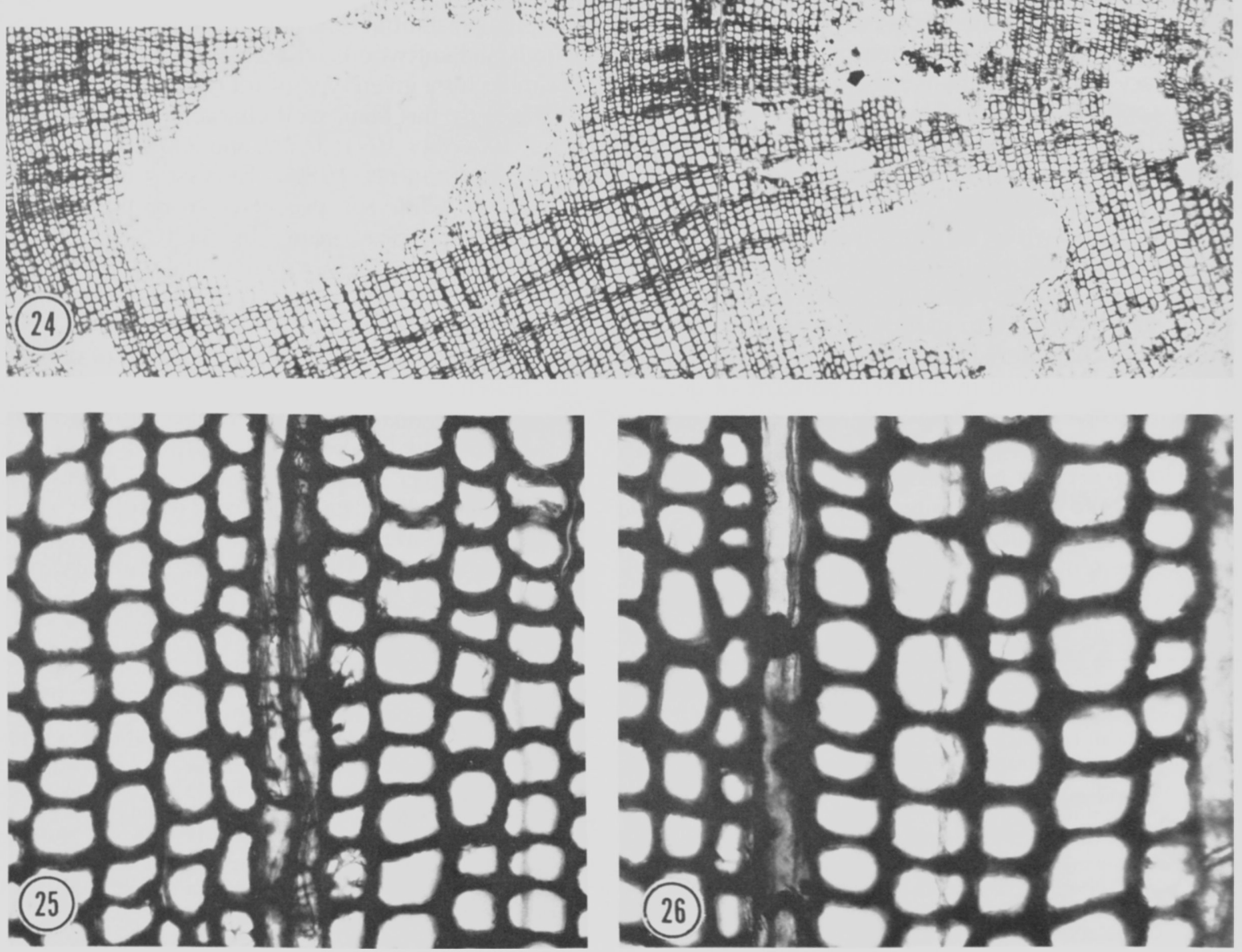
sidual thickened areas of compound middle lamella. Although these decayed cells were fibers, structural modifications were similar to those in the decayed tracheids of Araucarioxylon (fig. 5, A-F in WILCOX 1968).

White-pocket rot differs in several respects from white rot (BLANCHETTE 1980 b). Its most characteristic macroscopic feature is the production of discrete elongated or spindle-shaped pockets of decayed wood separated by areas of sound wood. The decayed areas consist of white cellulosic tissues largely devoid of lignin. Microscopically, whitepocket rot is characterized by the removal of the middle lamella and the separation of cells. Cell remains are fibrillar and are not characterized by erosion troughs or the "shot-hole" appearance of cell walls produced by white rot (OTJEN and BLANCHETTE 1984).

A number of white-pocket rot fungi and simultaneous white rot fungi are capable of selective delignification in a variety of extant hardwood and coniferous tree species (BLANCHETTE 1984). The same type of fungus is sometimes capable of producing both types of decay, and both decay processes may occur simultaneously in the same tissue (BLANCHETTE 1980 b). The presence of both patterns of degradation is indicated in our specimens. Areas of apparently delignified tracheids may correspond to the decay pockets typical of white-pocket rot, while empty pockets may be caused by the removal of the weak, delignified decayed wall material during fossilization. However, empty pockets are often bounded by partially degraded cells with persistent middle lamellae that suggest a simultaneous white rot. A possibly analogous situation was described by OTJEN and BLANCHETTE (1984) in oak decayed by Xylobolus frustulatus. As in the fossil material, both pockets of delignified cells and empty pockets were identified. The former were formed as the fungus selectively removed lignin. The latter were produced subsequently by the same fungus which "in a separate but successive process removed the remaining intact cellulose" (OTJEN and Blanchette 1984). In another example, decay in Quercus caused by Inonotus dryophilus produced delignified tissues adjacent to cells with the shot-hole appearance of white rot (OTJEN and BlanchetTe 1982).

Among the most interesting aspects of wood decay in extant trees is the response of the infected plant. A variety of responses to fungal invasion, which serve to isolate or compartmentalize in- fected tissue and thus prevent or retard further infection, have been described. These responses are known in both stems and roots. Among them is the production of axial parenchyma rich in polyphenols and traumatic resin ducts (SHIGo 1979; TIPPETT and SHIGO 1981). Another response involves the production of "barrier zones" that may appear as an abnormal "growth ring" (TIPPETT and SHIGO 1980). A third well-documented host reaction is the production of wall appositions or callosities (AIST 1976). The evidence of host response in the present fossil material is only suggestive. The most convincing evidence is the elaborated secondary walls seen in many tracheids in Araucarioxylon. Although the origin and function of these thickenings are not clear, they resemble wall appositions or callosities (see AIST 1976), and their absence in uninfected wood suggests that they may indeed be a response to fungal attack. Many stimuli, including mechanical damage, bacterial action, viral infection, and fungal attack, prompt their formation in extant plants, and they are known in the fossil record as well (STUBBLEFIELD et al. 1984).

Although callosities are customarily found in living cells, Shigo and ShortLe (1979) demonstrated the capability of heartwood to respond to fungal invasion, and it is also conceivable that the thickenings formed early in the development of the tracheid. Because they often occlude the cell lumen, they may have blocked hyphal growth-just as does the plugging of conducting cells by resin production in many modern plants. On the other hand, these structures intergrade in thickness with partially degraded cell walls, suggesting that they could be directly correlated with decay and represent an uneven swelling in the secondary wall caused during chemical degradation. In addition to wall elaborations, ray cells are customarily filled with a dark substance. Because ergastic substances are common in heartwood, the presence of filled tracheids cannot be definitely correlated with fungal activity in our material. However, since most modern woods with pocket rot have copious amounts of gums and resins in the tracheids between pockets (BLANCHETTE, personal communication), such substances are expected to accompany decay in our specimens.

WOOD DECAY IN THE FOSSIL RECORD.-Wood rot resulting from fungal activity is undoubtedly more common in the geologic past than has been recognized. Because the morphology and evolution of vascular plants have traditionally been the primary

Figs. 21-26.-Vertebraria. Fig. 21, Cross section of axis showing numerous pockets of decay and wedge-shaped aerenchymatous areas. CB 433D bot; $\times 1$. Fig. 22. Longitudinal section through secondary xylem showing spindle-shaped pockets. CB $433 \mathrm{D} ; \times 7$. Fig. 23, Poorly preserved hyphae in decayed area. CB 432C B-1B; $\times 175$. Fig. 24, Cross section of axis showing decayed areas and distorted growth rings. CB 432C B-3A s1. 7; $\times 30$. Fig. 25. Cross section of infected axis with fungi in ray parenchyma and several tracheids. CB 432A B-3A; $\times 176$. Fig. 26, Cross section of infected axis from area near that shown in fig. 25 showing hypha penetrating the tangential walls of adjacent tracheids. CB $432 \mathrm{~A}$ B-3A; $\times 150$. 
focus of paleobotanical studies, fungi in the fossil record are usually noted only in passing. However, because of the importance of fungi in wood decay today, it is reasonable to assume a major role for fungi in the destruction of plant tissues in the past. Collections of fossil woods from Gondwana continents support this assumption: e.g., decayed axes constitute ca. $60 \%$ of the specimens of Araucarioxylon available in our collection. Other specimens of perforate wood have been described from Gondwana, and, although the question of fungal involvement has been raised, it has not been investigated (e.g., Polysolenoxylon in MAHESHWARI 1972).

A similar situation exists in the Devonian of the Northern Hemisphere where the earliest documented wood rot occurs in the Famennian and was apparently caused by either ascomycetes or basidiomycetes (STUBBLEFIELD et al. 1985). The existence of higher fungi by this time, and the origin of lignified plant tissue even earlier, suggest that wood-decaying fungi may have been present early in the evolutionary history of land plants. The close similarity between present-day decay and that in the late Devonian and in the Permian and Triassic suggests little change in decay mechanisms.

An equally challenging and intriguing series of questions can be posed regarding the evolution of defense or compartmentalization mechanisms in Paleozoic plants. Although too few examples of Paleozoic wood decay have been studied in sufficient detail to allow generalization, the only evidence of defensive reactions in the Devonian was the production of resin. In more recent plants, wall appositions and the extensive production of ergastic substances are seen in an infected Upper Pennsylvanian gymnosperm (STUBbLEFIELD et al. 1984), and possible wall appositions are again present in our Permian material. Surprisingly, many of the responses illustrated in extant plants have not yet been demonstrated in infected fossil plants. Although their absence may merely reflect an insufficient sample of decayed wood, it may also indicate that the protective responses were not well developed until later in the course of plant evolution. An alternative is that in many instances the wood was already dead when it was attacked by fungi. Indeed, white-pocket rot occurs in living and dead trees. However, because probable wall ap- positions were present and resinous material accumulated in the ray parenchyma, we believe that in Araucarioxylon the fungus probably attacked a living tree. Evidence involving Vertebraria is inconclusive.

Other unanswered questions remain. At present we find no explanation for the distinctive pattern of decay-i.e., the shape of the pockets and their distribution in the stem. This is not surprising since experimental work with extant plants has also failed to provide a full explanation for the decay pattern characteristic of white-pocket rot (BLANCHETTE 1982). In addition, we cannot explain the absence of other organisms in the decayed woods since bacteria and yeasts are often associated with basidiomycetes during the decay of softwood (BLANCHETTE and SHAW 1978). They may be overlooked in LM because of their size, may be lost as permineralized material is prepared for SEM, or may not be preserved.

The discovery of wood decay in the fossil record is a valuable expansion of our knowledge regarding Paleozoic and Mesozoic ecosystems. It not only provides an indirect method of documenting the existence of major groups of fungi in geological history but also serves as a basis for characterizing the interaction between fungi and higher plants. As further instances of wood decay are documented, variation in decay patterns may also provide indirect evidence for changes in the biochemistry of fungal decay systems. The fossil record of fungi as known today strongly suggests that there has been relatively little change in the vegetative morphology of fungi from the Paleozoic to the present. However, this does not preclude the possibility of significant evolutionary changes in more dynamic areas of their biology. Fossil evidence for interaction between fungi and higher plants may provide insight into these more obscure problems.

\section{Acknowledgments}

This work would not have been possible without the collections of silicified plant material made by the late JAMES M. SCHOPF, who laid a foundation for paleobotanical studies in the Antarctic. This is contribution 532 of the Institute of Polar Studies, Ohio State University, and was supported in part by National Science Foundation grants DEB8213060, DPP-8213749, and BSR-8516323.

\section{LITERATURE CITED}

AIST, J. R. 1976. Papillae and related wound plugs of plant cells. Annu. Rev. Phytopatol. 14:145-163.

BarReTt, P. J. 1970. Paleocurrent analysis of the mainly fluviatile Permian and Triassic Beacon rocks, Beardmore Glacier area, Antarctica. J. Sedimentary Petrology 40:395-411

BLANCHETtE, R. A. 1980a. Wood decay: a submicroscopic view J. Forest. 78:734-737

$1980 b$. Wood decomposition by Phellinus (Fomes) pini: a scanning electron microscopy study. Can. J. Bot. 58:14961503
1982. Decay and canker formation by Phellinus pini in white and balsam fir. Can. J. Forest. Res. 12:538-544.

1984. Screening wood decayed by white rot fungi for preferential lignin degradation. Appl. Environ. Microbiol. 48:647-653.

Blanchette, R. A., and C. G. Shaw. 1978. Association among bacteria, yeasts, and basidiomycetes during wood decay. Phytopathology 68:631-637.

BoyCE, J. S. 1961. Forest pathology. 3d ed. McGraw-Hill. London. 572 pp. 
Bravery, A. F. 1971. The application of scanning electron microscopy in the study of timber decay. J. Inst. Wood Sci. $5: 13-19$

BRLES, C. T. 1936. Evidences for insect activity preserved in fossil wood. J. Paleontol. 10:637-643.

Cichan, M. A., and T. N. TAYloR. 1982. Wood-borings in Premnoxylon: plant-animal interactions in the Carboniferous. Palaeogeogr. Palaeoclimatol. Palaeoecol. 39:123-127.

Cowling. E. B. 1961. Comparative biochemistry of the decay of sweetgum sapwood by white-rot and brown-rot fungi. USDA Tech. Bull. no. 1258. USDA, Washington, D.C.

Eriksson, K.. A. Grunwald, T. Nillson, and L. Vallender. 1980. A scanning electron microscopy study of the growth and attack on wood by three white-rot fungi and their cellulase-less mutants. Holzforschung 34:207-213.

FISK. L. H. . and W. M. FrITZ. 1984. Pseudoborings in petrified wood from the Yellowstone "fossil forests." J. Paleontol. 58:58-62.

Gould, R. E., and T. E. Delevoryas. 1977. The biology of Glossopteris: evidence from petrified seed-bearing and pollen-bearing organs. Alcheringa 1:387-399.

JUTTE. S. M., and R. A. ZABEL. 1974. Initial wood decay stages as revealed by scanning electron microscopy. Scanning Electron Microscopy/1974 (pt. 2): 445-452.

LeVY, J. F. 1974. Fungi in wood. Scanning Electron Microscopy / 1974 (pt. 2): 461-468.

LINCK. O. 1949. Fossile Bohrgange an einem Keuperholz. Neues Jahrb. Mineral. Geol. Palaontol. Monatsch. 4-6:180-185.

MAheshwari, K. K. 1972. Permian wood from Antarctica and revision of some lower Gondwana wood taxa. Palaeontographica 138B: 1-43.

Montgomary, R. A. P. 1982. The role of polysaccharidease enzymes in the decay of wood by basidiomycetes. Pages $51-$ 65 in J. C. Frankland, J. N. Hedger, and M. J. Swift, eds. Decomposer Basidiomycetes. Cambridge University Press, Cambridge.

Otjen. L.. and R. A. Blanchette. 1982. Patterns of decay caused by Inonotus dryophilus (Aphyllophorales: Hymenochaetaceae), a white-pocket rot fungus of oaks. Can. J. Bot. 60:2770-2779

1984. Xilobolus frustulatus decay of oak: patterns of selective delignification and subsequent cellulose removal.
Appl. Environ. Microbiol. 47:670-676.

Prasad, M. N. V. 1982. An annotated synopsis of Indian Palaeozoic Gymnospermous woods. Rev. Palaeobot. Palynol. 38:119-156.

Schopf, J. M. 1965. Anatomy of the axis in Vertebraria. Pages 217-228 in J. B. HaDLEY, ed. Geology and paleontology of the Antarctic. Antarctic Research Ser. 6. American Geophysical Union, Washington, D.C.

1970. Petrified peat from a Permian coal bed in Antarctica. Science 169:274-277.

1971. Notes on plant tissue preservation and mineralization in a Permian deposit of peat from Antarctica. Am. J. Sci. 271:522-543.

SCURFIELD, G. 1979. Wood petrifaction: an aspect of biomineralogy. Aust. J. Bot. 27:277-390.

Shigo, A. L. 1979. Tree decay: an expanded concept. Agr. Inf. Bull., USDA no. $419.73 \mathrm{pp}$

Shigo, A. L., and W. C. Shortle. 1979. Compartmentalization of discolored wood in heartwood of red oak. Phytopathology 69:710-711

Sigleo, A. G. 1978. Organic geochemistry of silicified wood. Petrified Forest National Park, Arizona. Geochim. Cosmochem. Acta 42:1397-1405.

Stubblefield, S. P.. T. N. TAylor, and C. B. Beck. 1985. Studies of Paleozoic fungi. V. Wood-decay in the Upper Devonian progymnosperm, Callixvlon newberryi. Am. J. Bot. 72:1765-1773.

Stubblefield, S. P., T. N. Taylor, C. E. Miller, and G. T. COLE. 1984. Studies of Paleozoic fungi. III. Fungal parasitism in a Pennsylvania gymnosperm. Am. J. Bot. 71:12751282.

TIPPETT, J. A., and A. L. SHIGo. 1980. Barrier zone anatomy in red pine roots invaded by Heterobasidium annosum. Can. J. Forest. Res. 10:224-232.

- 1981. Barriers to decay in conifer roots. Eur. J. Forest. Pathol. 11:51-59

Walker, M. V. 1938. Evidence of Triassic insects in the Petrified Forest National Monument, Arizona. Proc. U.S. Natl. Mus. 85:137-141.

Wil.cox, W. W. 1968. Changes in wood microstructure through progressive stages of decay. U.S. Forest Service Research Paper FPL 70. 45 pp. 